\title{
'Pathophysiology and Incidence of Varicocoeles in Men : what an Infertility Specialist Should Know"
}

\author{
Dr. Kulvinder Kochar Kaur, MD ${ }^{1 *}$, Dr. Gautam Allahbadia, MD², Dr. Mandeep Singh, MD
}

${ }^{1}$ Scientific Director, Dr Kulvinder Kaur Centre for Human Reproduction, Jalandhar, Punjab, India.

${ }^{2}$ Scientific Director, Rotunda- A Centre for Human Reproduction, Bandra, Mumbai, India.

${ }^{3}$ Consultant Neurologist, Swami Satyanand Hospital, Baradri, Jalandhar, Punjab, India.

*kulvinder.dr@gmail.com

*Corresponding Author: Dr. Kulvinder Kochar Kaur, MD, Scientific Director, Dr Kulvinder Kaur Centre for Human Reproduction, 721, G.T.B. Nagar, Jalandhar-144001, Punjab, India.

\begin{abstract}
Varicocoeles or dilation of the pampiniform plexus involves 15\%of men.The etiology and pathogenesis of varicocoeles can not be explained by one theory.Valve dysfunction, ontogenic collateral formation and the nutcracker phenomenon appear to act synergistically. Hyperthermia, increased hydrostatic pressures and antisperm agents are suggested as possible causes for the pathophysiology of varicocoeles induced infertility.But the combination of patients lifestyles, genetic factors and the consequences of reflux into pampiniform plexus contribute to infertility. Though venography remains the gold standard, the combination of physical examination, color Doppler ultrasound and thermography has the highest sensitivity and specificity to diagnose a varicocoele. For infertility still search is there regarding strict criteria or grading, for deciding which patients might or may not benefit from treatment. This treatment of varicocoeles can be done using open surgical or percutaneous techniques. Treatment of varicocoeles of infertility is controversial, as most of men with varicocoeles remain fertile. Currently highest pregnancy rates were obtained by inguinal, or subinguinal microscopic surgery gave the highest pregnancy rates, and the lowest recurrence rates along with complication rates. But superselective glue embolization or sclerosing of the ISV are the best percutaneous alternatives and can be done as an out door patient basis under local anaesthesia, with faster return to normal activities than surgery.
\end{abstract}

Keywords: valve dysfunction; mutcracker phenomenon; hyperthermia; infertility; subinguinal microscopic surgery; superselective glue embolization.

\section{INTRODUCTION}

By definition varicocoele is defined as dilatation of the pampiniform venous plexus that drains the testicle.To diagnose it a physical examination of the scrotum is done and it gets graded as grade 1 varicocoele (palpable only during valsalva maneuver), grade II (palpable in the standing position, grade III- (visible without palpation) [1]. Earlier reviews on varicocoele gave its incidence to be $4.4-22.6 \%$, having an average of $15 \%$ [2]. In another study where 7035 military recruits got examined over 18years from 6 European countries. Only $1 \%$ had bilateral disease and $0.2 \%$ had isolated right sided varicocoeleon physical examination [3]. Yet prevalence might be high in those coming for primary infertility treatment ranging from $30-45 \%$ and $80 \%$ in those needing secondary infertility treatment $[4,5]$.

\section{MECHANISM OF VARICOCOELE FORMATION}

Normally blood from the testis drains into a network of veins called the pampiniform plexus. As per Ergun et al veins that drain from the testis can be separated into 2 bundles, one which is a collection of veins that are tightly wound around the testicular artery, and the other in the adjacent fatty tissue as proven by using cast preparations, light microscopy and computer aided 3 dimensional rconstruction [6]. Ultimately these two bundles coalesce into the internal spermatic vein at the level of the internal inguinal ring. Internal spermatic vein (ISV) dilation along with reflux of 
‘Pathophysiology and Incidence of Varicocoeles in Men: what an Infertility Specialist Should Know”

blood down into the pampiniform venous plexus, is considered to be the primary pathologic process in varicocele formation. Occasionally varicocoeles are the result of external compression of the ipsilateral renal vein or the spermatic vein itself that ultimately impedes testicular venous drainage.

Various processes are responsible for dilation and reflux in primary varicocoele. 1)Different studies on cadavers and venography studies confirm that the left, sometimes right internal spermatic vein drain into the renal vein or supra renal vein perpendicularly [7]. Patterns of drainage, and it has been seen that the left spermatic vein has a longer drainage tract in toto, and thus causes greater venous diffences in pressure that might explain greater incidence of left sided varicoceles with bilateral or isolated right sided varicoceles being a rarity [3, 8-10]. Thus the development of varicoceles is associated with somatometric parameters, which should change the length of venous drainage and hydrostatic pressures. Different studies have correlated increasing height being a factor associated with varicoceles, so that taller men have a higher incidence of varicoceles $[11,12]$. 2) Incompetence of venous valves along with variation in internal spermatic vein drainage is another factor that adds to the formation of varicoceles. Postmortem examination on men, in studies done previously showed either incompetence or absence of internal spermatic vein valves in $50 \%$ of men who got studied [13]. Recent studies have shown complete absence of valves in patients with varicocoeles [14], specially in adolescents [15]. Accessory or alternate connections between the internal spermatic vein and systemic venous circulation has been found, which does not have antirefluxing mechanisms $[15,16]$. One needs to take into consideration this variety of anatomic change when attempting to treat patients at a level that is distant from the point of testicular vein coalescing [17]. This might explain a much higher varicocoele recurrence following procedures like laparoscopic selective internal spermatic vein ligation and the percutaneous venous embolization of the internal spermatic vein $[18,19]$. 3) A rare mechanism of varicocoele formation is compression of the left renal vein or internal spermatic vein [20]. The nutcracker syndrome, where the renal vein is compressed in between the aorta and superior mesenteric artery, is postulated as a probable cause of internal spermatic vein insufficiency. According to some studies this might be associated with varicocoele development in adolescents, more than adults along with those having lower BMI $[15,21]$. There is possibility of a varicocoele getting caused by external compression that a tumor causes or due to malformations like situs inversus, thus it is advisable to examine cases of right sided varicocoeles and potentially new left sided varicocoeles in older men with the use of abdominal imaging [20, 22].

Extrafunicular veins are made up of cremasteric, external pudendal, gubernacular and deferential veins, that are anatomically different from testicular veins, of which all drain into the iliac vein. It is advocated that deferential veins should be spared during variococoelectomy, ligation of the rest of extrafunicular veins remains controversial. [23]0n venography it is shown that extrafunicular veins are not likely to add to the pathologic,refluxing primary or recurrent varicocoeles [24]. But based on the theory that varicocoeles depict an example of venous retrograde circuit where venous blood flow starts at the incompetent internal spermatic vein and then travel through the pampiniform plexus and out into the pelvic veins, ligation of some of these extrafunicular (like cremasteric veins) might help in closing the pathologic venous circuit [25]. Clinically it is seen that trying to attempt to ligate all extrafunicular veins other than deferential vein by delivering the testis provides no benefit in improving hormonal and semen parameters [25].

\section{PATHOLOGY OF VARICOCOELE}

The exact mechanism by which varicocoeles affect spermatogenesis is still not clear. Though it is clear that men having varicocoeles are associated with impaired semen parameters even when they are not trying for infertility treatment [3]. No single theory explains how varicocoeles directly affect spermatogenesis, commonest mechanisms have been derived from nonhuman models [26].

\section{Oxidative Stress}

Reactive oxygen species (ROS), are highly reactive oxygen containing chemical species, which are unavoidable byproducts of metabolic pathways,like mitochondrial respiration, that have been shown to impair spermatogenesis [27]. Mitochondria are the main source of sperm produced ROS, specially in the formation of superoxide in the electron 
transport chain [28]. Increased ROS production is associated with decreased sperm motility,abnormal sperm morphologyand reduced sperm adenosine triphosphate (ATP) production [29]. ROS may also damage the less mature spermatogonia,causing DNA and chromatin structural harm, which potentially =>germ cell apoptosis [30].

Higher oxidative stress is present in semen of patients seeking care for infertility [31]. DNA fragmentation $[30,32]$ is a consequence of abnormally high levels of ROS. This DNA integrity getting compromised thus can cause reduced fertility potential and might serve as the link between Varicocoeles and impaired semen quality [32,33], mainly once evidence exists that varicocoelectomy might reduce sperm DNA fragmentation and increase fertility potential [34, 35]. The reference ranges for both ROS and DNA fragmentation might vary based on the assay used in the laboratory.

\section{Toxin Accumulation (Secondary to Hypoper} fusion and Blood Stasis)

On testicular biopsies from men having varicocoeles has given the histological proof that there is stagnation of blood in microcirculatory vessels that causes ischaemic structural changes at the cellular level $[10,36]$. That hypoxia exists in men having varicocoeles has been studied at molecular level, with increased hypoxia inducible factor $1 \alpha$, which is a key regulator in tissue response to hypoxia, in ISV samples [37]. Further improvement of testicular arterial hemodynamics following varicocoelectomy have been shown by studies which further strengthen this theory that decreased local blood flow in testis results due to varicocoeles [38, 39].

\section{Hyperthermia Causing Heat Stress}

Lot of pointers are there regarding spermatogenesis getting impaired by scrotal hyperthermia and further there are publications which support heat stress getting used for contraception along with high fever affecting spermatogenesis [40]. Intratesticular along with skin temperatures have been found to be increased significantly in presence of varicocoeles as seen both in human and animal studies [41, 42]. How varicocoeles increase temperature has been explained on the basis of the modelof scrotal countercurrent heat exchange as explained by Dahl et al, and that heat is exchanged above the testis between vessels which carry blood to the testis and the vessels that are there within the testis [43]. Explanation at molecular level regarding how heat stress interferes with spermatogenesis is reduced production of proteins overall, with specifically important enzymes like topoisomerase I, DNA polymerase along with heat shock proteins [44, 45].

\section{Hypogonadism Associated with Varicocoele}

There is a suggestion that varicocoeles hamper the normal leydig cell function and number and in turn the sertoli cell function and thus affecting the serum testosterone (T) levels, whose levels are important for maintenance of spermatogenesis and fertility. Once the varicocoeles gets repaired it causes restoration of normal serum androgen levels causing reversal of symptomatic hypogonadism, along with impaired spermatogenesis. As early as 1970's it was shown that varicocoele repair is associated with $\mathrm{T}$ improvement in impaired levels [46]. Testicular function has been shown to be temperature dependent and all these toxin accumulation, heat stress, along with oxidative stress might directly affect the leydig cell function of the testis, that are responsible for the normal intratesticular $\mathrm{T}$ concentrations required for spermatogenesis [47].

95\% of the total serum $\mathrm{T}$ secretion comes from the Leydig cells in adult men. There is a 5 step enzymatic synthetic pathway that is directly under the control of LH secretion from pituitary leading to $\mathrm{T}$ biosynthesis [48]. Intracellular cyclic AMP-Protein Kinase A signaling gets stimulated by $\mathrm{LH}$, that promotes trafficking of cholesterol precursor from the cytoplasm to mitochondria by the help of steroidogenic acute regulatory protein (StAR) $[49,50]$. This trafficking of cholesterol with the help of StAR is the rate limiting step in $T$ synthesis, with in vitro studies showing that inhibition of StAR protein expression and activity results due to oxidative stress. [51] Marked reduction of both serum and intra testicular levels of $\mathrm{T}$ has been shown by in vivo studies on challenge with chronic hypoxia which then leads to elaboration of ROS in the testis $[52,53]$. In human patients with obstructive sleep apnea and those exposed to high altitude cause a similar phenomena causing decrease in serum $\mathrm{T}$ and oligospermia [54, 55]. Varicocoele causing heat stress impacts on the testicular function. In nonhuman studies a direct toxic effect on the leydig cell viability as well as $\mathrm{T}$ production occurs following heat stress. 
‘Pathophysiology and Incidence of Varicocoeles in Men: what an Infertility Specialist Should Know”

These processes related to heat stress are carried out by endoplasmic reticulum, which is an organelle that is essential in maintaining cellular homeostasis under conditions of stress, that activates a cascade at the intracellular at level called the unfolded protein response [56]. Heat induced protein misfolding gets detected secondary to this heat stress response, along with ultimate degradation of these proteins causing a full stop to protein translation. Once this heat stress response gets chronic in nature the unfolded protein response cascade activates proapoptotic pathways,causing cell death [57]. To examine the effect of heat stress on leydig cell function and its viability, tissue culture and live models got used by various researchers [58]. Using a, tissue culture cell line of mouse leydig tumour cells responsivity to HCG, they showed a definite increase in stress response mediator proteins and a simultaneus reduction in HCG induced steroidogenic activity. Both hormonal levels as well as important enzymes involved in $\mathrm{T}$ synthesis pathways were decreased. This heat stress mediated reduction in steroidogenesis could be recapitulated using a live mouse model. Following several cycles of heat exposure to $42^{\circ} \mathrm{C}$ for 15 , various steroidogenicenzymes like StAR, and serum $\mathrm{T}$ levels got reduced. This reduction could be reversed with giving taurourso deoxy cholic acid (TUDCA) injected intraperitoneally, that is a known endoplasmic reticulum stress inhibitor. Histologically mice that had undergone heat stress again and again showed leydig cell death along with activation of preapoptotic cellular cascades that also were reversed by administering TUDCA.

Lot of nonhuman models have been studied to confirm that a direct pathologic consequence of anatomic varicocoeles on leydig cell viability exists. A sham controlled experiment in rats with surgically induced left sided varicoceles was conducted by Luo et al [59]. 4and 8 weeks later, following varicocoele induction, apoptosis of leydig cells and reduced $\mathrm{T}$ biosynthesis was revealed on biochemical studies that was associated with considerable decrease In intraT levels in the varicocoele group versus the sham group at 8 weeks (24.84vs $29.41 \mathrm{ng} / \mathrm{g}$; $<<0.05$ ). In the same study immunohistological examination showed a statistically significant increase in leydig cell apoptotic index in the varicocoele group as compared to the sham group at 4 and 8 week $(p<0.01)$, and significant decrease in StAR mRNA expression getting seen in the right testis i.e normal one as compared to the left testis i.e the varicocoele one in the experimental group,that implies there are systemic effects of surgically induced varicocoele. ie. In one experimental model other enzymatic defects were shown to inhibit $\mathrm{T}$ production by leydig cells at the 17, 20 -desmolase step in the biosynthetic pathway [60]. Another study in which rats underwent surgically induced varicocoeles with repair, was done by Ozturk et al [61]. 4weeks after repair intra $\mathrm{T}$ levels were examined and a statistically significant increase in serum $\mathrm{T}$ in the repair group as compared to rats that did not have varicocoelectomy, which shows by varicocoelectomy, there is reversal of the hypogonadism induced by varicocoele.

In case of adult humans there have been a lot of studies that have shown a definite effect of varicocoele repair on serum T levels. In 1995, a retrospective study was done by Su et al [62]. They found a rise in serum $\mathrm{T}$ from $319+-12 \mathrm{mg} / \mathrm{dl}$ preoperatively to $409+-n g / d l(p<0.004)$ after inguinal or subinguinal microsurgical varicocoele repair in 33men who had presented with infertility. Other studies verified these since 1995 [25, 63-65], while others failed to show any increase in T following varicocoelectomy [66-68]. The problem in studies where effect of varicocoele repair was not reflected was that most of them had a normal preoperative serum $T$ levels, with any change in there levels was a secondary outcome, and no change detected due to insufficient statistical power and variability in measurement of serum $\mathrm{T}$ levels. However recent prospectively done studies confirm a clinically statistically significant rise on serum $\mathrm{T}$ after varicocoelectomy in hypogonadal men [69-71]. A meta-analysis that got carried out in 2012 of nine studies having $818 \mathrm{men}$ showed a mean increase in serum $\mathrm{T}$ of $97.48 \mathrm{ng} / \mathrm{dl}(95 \% \mathrm{CI} 43-7-151.22 ; \mathrm{P}=0.004)$ from intraoperative levels [72]. Translation into improved clinically significant symptoms is to be seen.

\section{Conclusions}

From this review, it is seen that not only there is prevalence of varicocoeles, they also add to pathology (fig1 for summaryof pathogenesis) which alters semen parameters, along with testosterone production.The anatomy of these varicocoeles are of importance, especially the veinous drainage paths, since they affect the efficacy of a treatmnent, mainly if one uses embolization or high ligation of the ISV. Various theories exist at the molecular level, that explain the impaired 
'Pathophysiology and Incidence of Varicocoeles in Men: what an Infertility Specialist Should Know"

semen parameters, along with $\mathrm{T}$ production, yet as it might be of help for the treating physician there are many theories which still have no proof. Still it is important that the treating clinicians understand this anatomy,along with mechanisms by which varicocoele affect testicular function, regarding counseling the patient to choose an option for treatment and discuss the causes of recurrences and complications of treating these varicocoeles.

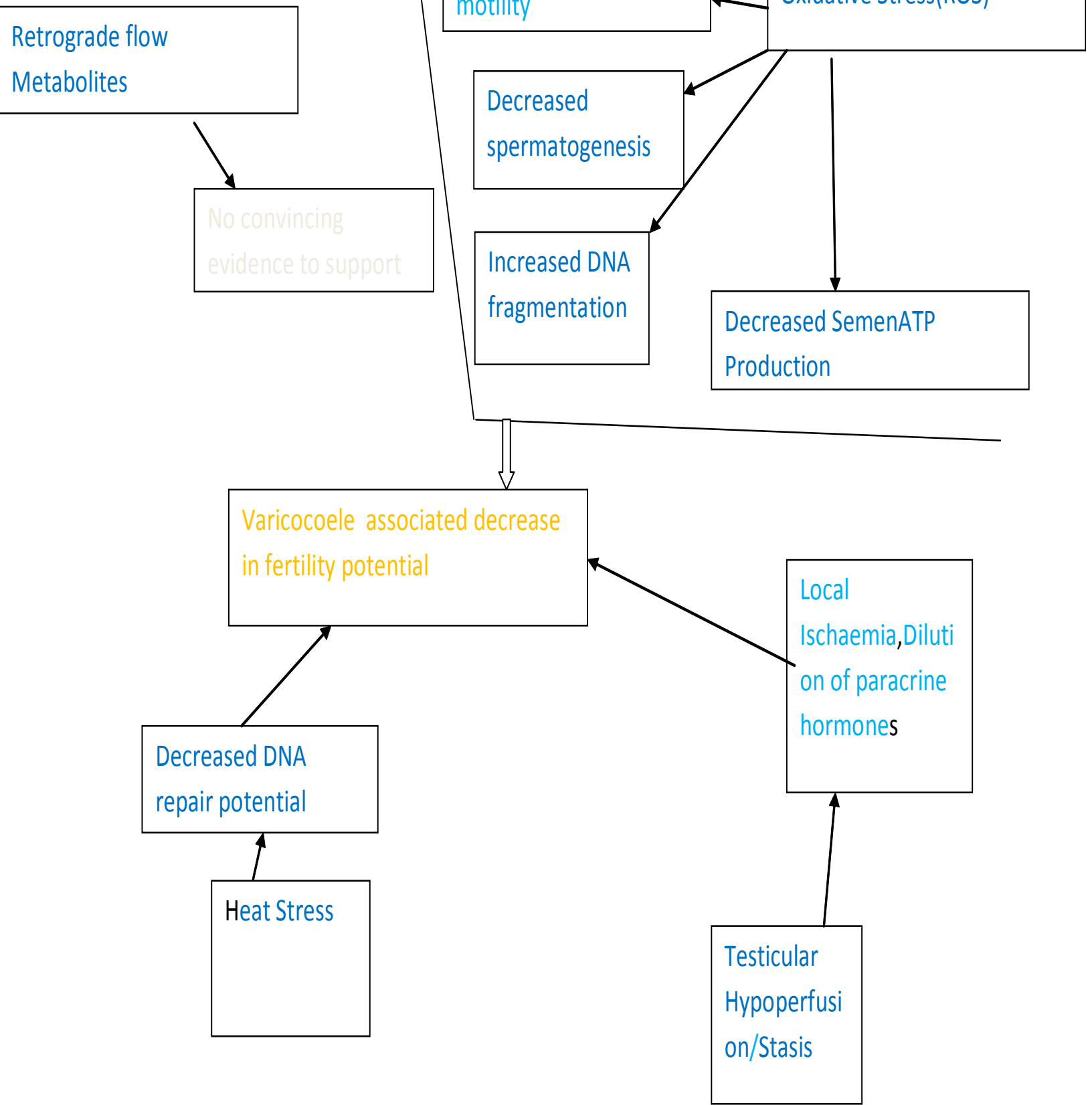

Fig 1. Proposed molecular mechanisms for the pathologic impact of varicocoeles on fertility potential $A T P=$ Adenosine riphosphate; $R O S=$ Reactive oxygen species 
‘Pathophysiology and Incidence of Varicocoeles in Men: what an Infertility Specialist Should Know”

\section{REFERENCES}

[1] Dubin L, Amelar RD. Varicocoele size and results of varicooelectomyin selected subfertile men with Varicocoele. Fertil Steril 1970; 21: 606-9.

[2] Saypol DC. Varicocoele J Androl 1981; 2: 61-71.

[3] Damasgaard J, Joensen UN, Carlsen E, Eren preiss], Bloomberg-Jensen M, Matulevicius V, etal. Varicocoele is associated with inpaired semen quality and reproductive hormone levels :a study of 7035 healthy young menfrom six European countries. Eur Urol 2016; 70: 1019-29.

[4] Jarow JP, Coburn M, Sigman M. Incidence of Varicocoeles in men with primary and secondary infertility. Urology 1996; 47: 73-6.

[5] Gorelick JL, Goldstein M. Loss of fertility in men with Varicocoele. Fertil Steril 1993; 59: 613-6.

[6] Ergun S, Bruns T, Soyka A, Tauber R. Angioarchitecture of the human soermatic cord. Cell Tissue Res 1997; 288: 391-8.

[7] Asala S, Chaudhary SC, Masumbo-Khamba N, Bidmos M, Anatomical variations in the human testicular blood vessels. Ann Anat 2001; 183: 545-9.

[8] Shafik A, Bedeir GA. Venous tension patterns in cord veins. In normal and Varicocoele individuals. J Urol 1980; 123: 383-5.

[9] Coolsaet BL. The Varicocoele syndrome: venography determining optimal level for surgical management.J Urol 1980; 124: 833-9.

[10] Gat Y, Zukerman Z, Chakraborty J Gornish M. Varicocoele, hypoxia and male infertility. Fluid mechanics analysis of the impaired testicular venous drainage systems. Hum Reprod 2005: 20: 2614-9.

[11] Bae K, Shin HS, Jung HJ, Kang SH, Jin BS, Park JS, Adolescent Varicocoele: are somatometric patterns a cause? Korean J Urol 2014; 55: 533-5.

[12] Delaney DP, Carr MC, Kolon TF, Snyder HM, Zderick SA. The physical characteristics of young men with Varicocoele. BJU Int 2004; 94: 624-6.

[13] Ahlberg NE, Barley O, Chidekei N. Retrograde contrast filling of the left gonadal vein: a roentological and anatomic study. Acta Radiol Diagn (Stockh) 1965; 3: 385-92.
[14] Dennison AR, Tibbs S J. Varicocoele and varicose veins compared a basis for logical surgery. Urology 1986; 28: 211-7.

[15] Vanlan gen hove P, Dhondt E, Maele GV, Van Wasberghe S, Delanghe E, Defreyne L. Internal spermatic artery insufficiency In Varicocoeles: a different entity in adults and adolescents? Am J Roentegenol 2015; 205: 667-75.

[16] Sze D Y, Kao J S, Frisoli J K, Mc Callum SW, Kennedy WAII, Razavi MK, Persistent and recurrent postsurgigal Varicocoeles: venographic anatomy and treatment with N-butyl cyanoacrylate embolization. J Vasc Interv Radiol 2008; 19: 539545.

[17] Naggappan P, Keene D, Ferrara F, Shabani A, Cervellone R M. ntrgrade venography identifies parallel venous duplications in the majority of adolescents with Varicocoele. J Urol 2015; 193: 286-90.

[18] Halpern J, Mittal S, Preira K, Bhatia S, Ramasamy R. Percutaneous embolization of Varicocoele: technique, indications, relative contraindications, and complications. Asian J Androl 2016; 18: 234-8.

[19] Al-Kandari AM, Shabaan H, Ibrahim HM, Elsheiny YH, Shokeir AA. Comparison of different Varicocoelectomy techniques: open inguinal, lalaparoscopic, and subinguinal microscopic Varicocoelectomy: a randomized clinical trial. Urology 2007; 69: 417-20.

[20] Lewis DS, Grimm LJ, Kim CY. Left renal vein compression as a cause for Varicocoele: prevalence and associated findings on contrast enhanced CT. Abdom Imaging 2015; 40: 314751.

[21] Handel LN, Shetty R, Sigman M. The relationship between Varicocoeles and obesity. J Urol 2006; 176: 2138-40.

[22] Preziosi P, Miano R, Bitelli M, Ciolfi MG, Micali S, Micali F. Right Varicocoele associated with inferior vena cava malformation in situs inversus: percutaneous treatment with retrograde sclerotherapy. J Endo urol 2001; 15: 1001-3.

[23] Glodstein M, GilbertBR,DickerAP,Dwosh J,Grecco C. Microsurgical inguinal Varicocoelectomy with delivery of the testis: an artery and lymphtic sparing technique. J Urol 1992; 148: 1808-11. 
'Pathophysiology and Incidence of Varicocoeles in Men: what an Infertility Specialist Should Know"

[24] Franco G, Lori F, De Dominics C, Dal Forno S, Mander A, Laurenti C. Challenging the role of cremasteric reflux in the pathogenesis of Varicocoele using a new venographic approach. J Urol 1999; 161: 1323-6.

[25] Ramaswamy R, Schlegel PN. Microsurgical inguinal varicocoelectomy with and without testicular delivery. Urology 2006; 68: 1323-6.

[26] Agarwal A, Hamada A, Esteves SC, Insight into oxidative stress in Varicocoele associated infertility: part I. Nat Rev Urol 2012; 9: 678-90.

[27] Sharma RK, Agarwal A. Role of reactive oxygen species in male infertility. Urology 1996; 48: 835850.

[28] Amaral A, Lourenco B, Marques M, RamalhoSantos J. Mitochondrial functionality and spermquality. Reprduction 2013; 146: R163-74.

[29] Gvozdjakova A, Kucharska J, Dubravicky J, Mojto V, Singh RB. Coenzyme Q10, $\alpha$ tocopherol, and oxidative stress could be importanmetabolic markers of male infertility. Dis Markers 2015; 2015: 827941.

[30] Agarwal A, Mlgund Alshahrani S, Assidi M, Abuzenadah AM, Sharma R, et al. Reactive oxygen species and sperm DNA damage in in infertile men pesenting with low level leukocytosperma. Reprod Biol Endocriol 2014; 12: 126.

[31] Agarwal A, Prabakaran S, Allameni SS. Relationship between stress, varicocele and infertility: a meta-anaysis. Reprod Biomed Online 2006; 12: 630-3.

[32] Lopes S, Juriscova A, Sun JG, Casper RF. Reactive oxygen species: potential cause for DNA fragmentation in human spermatozoa. Hum Reprod 1998; 13: 896-900.

[33] Erenpreiss J, Hlevicka S, Zalkalns J, ErenpreisaJ. Effect of leukocytosperma on sperm DNA integrity: a negative effect in abnormal semen samples. J Androl 2002; 23: 717-23.

[34] Esteves SC, Sanchez-Martin F, Sanchez-Martin P, Schneider DT, Gosalvez J. Comparison of reproductive outcomes in oligozoospermic men with high sperm DNA fragmentation undergoing intracytoplasmic sperm injection with ejaculated and testicular sperm. Fertil Steril 2015; 104: 1398-405.
[35] Kirby EW, Wiener LE, Rajana hally S, Crowell $\mathrm{K}$, Coward RM. Undergoing varicocoele repair before assisted reproduction improves pregnancy rate and live birthrate in azoospermic and oligozoospermic men with a varicocoele: a systematic review and meta-analysis. Fertil Steril 2016; 106: 1338-43.

[36] Chakraborty J, Hikim APS, Jhunjhunwala JS. Stagnation of blood in the microcircuilatory vessels in the testes of men with varicocoele. J Androl 1985; 6: 117-26.

[37] Lee JD, Jeng SY, Lee TH. Increased expression of hypoxia-inducible factor- $1 \alpha$ in the internal spermatic vein of patients with varicocoele. J Urol 2006; 175: 1045-8.

[38] Tarhan S, Ucer O, Sahin MO, Gumus B. Longterm effects ofmicrosurgicalinguinalvaricocoelectomy on testiculat blood flow. J Androl 2011, 32: 33-9.

[39] Zhang M, Du L, Liu Z, Qi H, Chu Q. The effect of varicocoelectomy on testicular arterial blood flow:laparodcopic surgery versus microsurgery. Urol J 2014; 11: 1900-6.

[40] Jung A, Schuppe C. Influence of genital heat stress on semen quality in humans. Andrologia 2007; 39: 203-15.

[41] Goldstein M, Eid JF. Elevation of intratesticular and scrotal skin temperature in men with varicocoele. J Urol 1989;142:743-5.

[42] Green KF, Turner TT, Howards SS. Varicocoele reversal of the testicular blood flowand temperature effects by varicocoele Repair. J Urol 1984; 131: 1208-11.

[43] Dahl EV, Herrick JF. A vascular mechanism for maintaining testicular temperature by counter current exchange. Surg Gynecol Obstet 1959; 108: 697-705.

[44] Hosseinifar H, Gourabi H, Salekdeh GH, Alikhani M, Mirshahvaladi S, Sabbaghian M, et al. Study of sperm protein profile in men with and without varicocoele using two dimensional gel electrophoresis. Urology 93-2013; 81: 293-300.

[45] Fujisawa M, Yosdida S, Kojima K, Kamidono S.Biochemical changes in testicular varicocoele. Arch Androl 1989; 22: 149-159.

[46] Comhaire F, Vermuelen A. Plasma testosterone in 
'Pathophysiology and Incidence of Varicocoeles in Men: what an Infertility Specialist Should Know'

patients with varicocoele. And sexual inadequacy. J Clin Endocrinol Metab 1975; 40: 824-9.

[47] Naughton CK, Nangia AK, Agarwal A. varicocoele and male infertility, partII: pathophysiology of varicocoeles in male infertility. Hum Reprod Update 2001; 7: 473-81.

[48] Dabaja A, Wosnitzer M, Goldstein M. Varicocoele and hypogonadism. Curr Urol Rep 2013; 14: 30914.

[49] Clark BJ, Wells J, King SR, Stocco DM. The purification, cloning and expression of a novel luteininzing hormone-induced mitochondrial protein in MA10 mouse leydig tumour cells. Characterization of the steroidogenic acute regulatory protein (StAR)protein and steroidogenesis. Endocrinology 1994; 269: 28314-22.

[50] Miller WL, Auchus RJ. The molecular biology, biochemistry, and physiology in human steroidogenesisand its disorders. Endocr Rev 2011; 32: 81-151.

[51] Amitochondria in MA10 tumour leydig cells an inhibits acute regulatory protein (StAR) and steroidogenesis. Endocrinology 2003; 144: 2882-91.

[52] Barnhoff KE, Hoffman AR, Rock PB, Muza SR, Fulco CS, Braun B, et al. Endocrine responses to acute and chronic high altitude exposure (4300 meters) modulating effect of calorie restriction. Am J Physiol Endocrinol Metab 2006; 290: E1078-88.

[53] Farias JG, Bustos-Obregon E, Tapia BJ, Gutierrez E,Zepeda M, Juantok C, et al. Time course of endocrine changes in the hypophysis-gonad axis induced by hypobaric hypoxia in rats. J Reprod Dev 2008; 54: 18-21.

[54] Benso A, Broglio F, Almaretti G, Lucatello B, Lanfraco F, Ghigo E, et al. Endocrine and metabolic responses to extreme altitude and physical exercise in cimbers. Eur J Endocrinol 2007; 157: 733-40.

[55] Liu PY, Caterson ID, Grunstein RR, Handelsman DJ. Androgens, obesity, and sleep -disordered breathing in men. Endocrinol Metab Clin North Am 2007; 36: 349-63.
[56] Schroder M, Kaufman RJ. ER stress and the unfolded protein response. Mutat Res 2005; 569: 29-63.

[57] Wang XZ, Lawson B, Brewer JW, Zinszner H, Sanjay A, MiI J, et al. Signals from the stressed endoplasmic reticulum induced C/EBPhmologous protein (CHOP/GADD 153). Mol Cell Biol 1996; 16: 4273-80.

[58] Kim JH, Park SJ, Kim TS, Lee DS. Testosterone production by a leydig tumour cll line is suppressed by hyperthermia induced endoplasmic reticulumstress in mice Life Sci 2016; 146: 184-91.

[59] Luo DY, Yang G, Liu JJ, Yang YR, Dong Q. Effects of varicocoele on testosterone, apoptosis and expression of StAR MRNA in rat leydig cells. Asian J Androl 2011; 13: 287-91.

[60] Rajfer J, Turner TT, Rivera F, Howards SS, Sikka SC.Inhibition of testicular testosterone biosynthesis following experimental varicocoele in rats. Biol Reprod 1987; 36: 933-7.

[61] Ozturk MI, Koca O, Kates MO, Haklar G, Baykan 0 , Erkan F,etal. The impact of unilateral experimental rat varicocoele model on testicular histopathology, Leydig cell counts, and intratesticular testosterone levels of both testis. Urol J 2013; 10: 973-80.

[62] Su LM, Goldstein M, Schlegel PN. The effect of varicocoelectomy on serum testosteronelevels in men with varicocoeles. J Urol 1995; 154: 1752-5.

[63] Cayan S, Kadioglu A, Orhan I, Kandirali E, Tefekli A, Tellaoglu S. The effect of microsurgical varicocoelectomy on serum follicle stimulating hormone, testosterone and free testosterone in infertile men with varicocoele. BJU Int 1999; 84: 1046-9.

[64] Tanrikut C, Goldstein M, Rosoff JS, LeeRK, Nelson CJ, Mulhall JP. Varicocoele as a risk factor for androgen deficiency and effect of repair. BJU Int 2011; 108: 1480-4.

[65] Gat Y, Gornish M, Belenky A, Bachar GN. Elevation of serum testosterone and free testosterone after embolization of the internal spermatic vein for the treatment of varicocoele in in infertile men. Hum Reprod 2004; 19: 2303-6. 
'Pathophysiology and Incidence of Varicocoeles in Men: what an Infertility Specialist Should Know'

[66] Pasqualatto FF, Lucon AM, De Goes PM, Sobreiro BP, Hallak J, Pasqualatto EB, et al. s it worthwhile to operate on subclinical right varicocoele in patients with grade II-III varicocoeles in the left testicle.J Assist Reprod Genet 2005; 22: 227-31.

[67] Di Bisceglie C. Betagna A, Baldi M, Lanfranco F, Tagliaube M, Gazzera C, et al. Varicocoele sclerotherapy improves serum inhibin B levels and seminal parameters. Int J Androl 2007; 30: 531-6.

[68] Ozden C, Ozdal O, Bulut S, Guzel O, Koyuncu $\mathrm{HH}$, Memis A. Effect of varicocoelectomy on serum inhibin Blevels in infertile patients with varicocoele. Scand J Urol Nephrol 2008; 42: 441-3.

[69] Zohdy W, Ghazi S, Arafa M. Impact of varicocoelectomy on gonadal and erectile functions in men with hypogonadism and infertility. J Sex Med 2011; 8: 885-93.
[70] Sathya Srini V, Berul Veerachari S. Does varicocoelectomy improve gonadal function in men with hypogonadism and infertility? Analysis of a prospective study. Int J Endocrinol 2011; 2011: 916380.

[71] Abdel Mequid TA, Farsi HM, Al-Sayyad A, Tayib A, Mosli HA, Halawani AH. Effects of varicocoeleon serum testosterone and changes of testosterone after varicocoelectomy:a prospective controlled study.Urology 2014; 84: 1081-7.

[72] Li F, Yue H, Yamaguchi K, Okada K, Matsushita $\mathrm{K}$, Ando $\mathrm{M}$, et al. Effect of surgical repair on testosterone production I infertile men with varicocoele:a meta-analysis. Int J Urol 2012; 19 : 149-54.

Citation: Dr. Kulvinder Kochar Kaur, MD, Dr. Gautam Allahbadia, MD, Dr. Mandeep Singh, MD. 'Pathophysiology and Incidence of Varicocoeles in Men: what an Infertility Specialist Should Know'. Archives of Urology. 2018; 1(2): 29-37.

Copyright: (C) 2018 Dr. Kulvinder Kochar Kaur, MD, Dr. Gautam Allahbadia, MD, Dr. Mandeep Singh, MD. This is an open access article distributed under the Creative Commons Attribution License, which permits unrestricted use, distribution, and reproduction in any medium, provided the original work is properly cited. 